\title{
Evaluation of immunological, inflammatory, and oxidative stress biomarkers in gasoline station attendants
}

\author{
Angela Maria Moro ${ }^{1,2}$, Elisa Sauer ${ }^{1,3}$, Natália Brucker ${ }^{1,4}$, Mariele Feiffer Charão ${ }^{1,5}$, Bruna Gauer ${ }^{1,3}$, \\ Sabrina Nunes do Nascimento ${ }^{1,3}$, Gabriela Goethel ${ }^{1,3}$, Marta Maria Medeiros Frescura Duarte ${ }^{6}$ and \\ Solange Cristina Garcia ${ }^{1,3^{*}}$
}

From 2nd Latin American Congress of Clinical and Laboratorial Toxicology

Porto Alegre, Brazil. 3-6 June 2018

\begin{abstract}
Background: Gasoline is a complex mixture of saturated and unsaturated hydrocarbons, in which aromatic compounds, such as BTX (benzene, toluene, and xylene) feature as the main constituents. Simultaneous exposure to these aromatic hydrocarbons causes a significant impact on benzene toxicity. In order to detect early alterations caused in gasoline station attendants exposed to BTX compounds, immunological, inflammatory, and oxidative stress biomarkers were evaluated.
\end{abstract}

Methods: A total of 66 male subjects participated in this study. The gasoline station attendants (GSA) group consisted of 38 gasoline station attendants from Rio Grande do Sul, Brazil. The non-exposed group consisted of 28 subjects who were non-smokers and who had no history of occupational exposure. Environmental and biological monitoring of BTX exposure was performed using blood and urine.

Results: The GSA group showed increased BTX concentrations in relation to the non-exposed group $(p<0.001)$. The GSA group showed elevated protein carbonyl (PCO) levels and pro-inflammatory cytokines, decreased expression of CD80 and CD86 in monocytes, and reduced glutathione S-transferase (GST) activity compared to the non-exposed group $(p<0.05)$. BTX levels and trans,trans-muconic acid levels were positively correlated with proinflammatory cytokines and negatively correlated with interleukin-10 contents $(p<0.001)$. Increased levels of proinflammatory cytokines were accompanied by increased PCO contents and decreased GST activity $(p<0.001)$. Furthermore, according to the multiple linear regression analysis, benzene exposure was the only factor that significantly contributed to the increased pro-inflammatory cytokines $(p<0.05)$.

Conclusions: Taken together, these findings show the influence of exposure to BTX compounds, especially benzene, on the immunological, inflammatory, and oxidative stress biomarkers evaluated. Furthermore, the data suggest the relationship among the evaluated biomarkers of effect, which could contribute to providing early signs of damage to biomolecules in subjects occupationally exposed to BTX compounds.

Keywords: Occupational toxicology, Benzene, Toluene, Xylene, CD80, CD86, Pro-inflammatory cytokines, Antiinflammatory cytokines, Protein carbonyl, Glutathione S-transferase

\footnotetext{
*Correspondence: solange.garcia@ufrgs.br

'Laboratory of Toxicology (LATOX), Department of Analysis, Pharmacy

Faculty, Federal University of Rio Grande do Sul, Porto Alegre, RS, Brazil

${ }^{3}$ Post-graduate Program in Pharmaceutical Sciences, Federal University of Rio

Grande do Sul, Avenida Ipiranga 2752, Santa Cecília, Porto Alegre, RS CEP:

90610-000, Brazil

Full list of author information is available at the end of the article
}

(c) The Author(s). 2019 Open Access This article is distributed under the terms of the Creative Commons Attribution 4.0 International License (http://creativecommons.org/licenses/by/4.0/), which permits unrestricted use, distribution, and reproduction in any medium, provided you give appropriate credit to the original author(s) and the source, provide a link to the Creative Commons license, and indicate if changes were made. The Creative Commons Public Domain Dedication waiver (http://creativecommons.org/publicdomain/zero/1.0/) applies to the data made available in this article, unless otherwise stated. 


\section{Background}

Gasoline station attendants are an important group at occupational risk to BTX (benzene, toluene, and xylene) compounds [1-3]. Among the constituents of gasoline, benzene stands out for its hazardous effects on human health [4-6]. Furthermore, simultaneous exposure to benzene and other aromatic hydrocarbons, such as toluene and xylene, contributes to maximizing benzene toxicity [7].

Benzene exposure in occupational settings has been progressively decreased as a result of preventive actions [8]. However, there are health concerns for workers related to low levels of occupational exposure. These concerns are linked to the fact that benzene is a well-recognized genotoxic human carcinogen, classified as a Group I chemical by the International Agency for Research on Cancer, and without any known threshold dose [3].

In addition, it is well known that the hematologic disorders, leukemia and myelodysplastic syndrome are caused by occupational benzene exposure, as well as various deleterious effects on many other biological systems after long-term exposures [9, 10]. Epidemiological and experimental studies have shown that benzene exposure can lead to non-cancer health effects, such as, genotoxicity, hematotoxicity, hepatotoxicity and nephrotoxicity $[2,11$, 12]. The mechanisms of benzene toxicity remain elusive. However, it is well-known that reactive oxygen species (superoxide anion, hydrogen peroxide, hydroxyl radical) resulting from benzene metabolism may damage biomolecules, inducing oxidative stress $[10,11]$.

Biomonitoring is a mandatory health protection measure for workers occupationally exposed to benzene [13, 14]. Biological monitoring has been used as a potential tool for better assessing integrated benzene exposures and may contribute to the diagnosis and treatment of occupational diseases [15]. Since there are no safe limits for exposures to carcinogens such as benzene, simultaneous evaluation of biomarkers of exposure and effect may be useful in the estimation and reduction of risks caused by occupational exposure to this xenobiotic. Such assessments may also be adopted for preventative health initiatives for improving the safety of occupationally exposed workers $[9,16]$.

A number of previous studies by our research group were conducted with the aim of establishing new biomarkers of early damage, which might be helpful in biomonitoring actions related to occupational exposure to benzene. Many early biomarkers of genetic [11], hematological [4], renal, hepatic [2], and immunological [2, 17] alterations, caused by low levels of occupational benzene exposure, were proposed for the continuous monitoring of occupational benzene hazards. Furthermore, these findings may be key elements in the elucidation of different benzene toxicity mechanisms.

Based on immunological biomarkers previously proposed by Moro et al. [4], the work conducted by Sauer et al. [17] showed possible immunotoxicity and carcinogenicity mechanisms arising from benzene exposure. Furthermore, alterations in inflammation biomarkers were also reported by Sauer et al. [17]. In order to continue the previous studies of our research group, this paper aimed to evaluate immunological, inflammatory, and oxidative stress biomarkers in gasoline station attendants, and verify the possible influence of benzene exposure on these biomarkers of effect.

\section{Methods}

\section{Study population}

Sixty-six individuals were enrolled in this study. The exposed group consisted of 38 gasoline station attendants (GSA) from Rio Grande do Sul, Brazil. All subjects had been working in their current job position for at least 6 months. The non-exposed (NE) group consisted of 28 subjects who were non-smokers and who had no history of occupational exposure to benzene or other xenobiotics. Each participant was interviewed about aspects of general health, lifestyle, smoking status, and history of exposure.

The average ages of the GSA and control groups were $32.1 \pm 1.7$ years and $30.4 \pm 1.8$ years, respectively. No significant difference between the GSA and control groups was found related to age. The mean exposure time in the GSA group was $8.5 \pm 1.6$ years (range: $0.5-32$ years).

This study was approved by the research ethics committee of the Federal University of Rio Grande do Sul/RS (No. 21728/11) and written informed consent was obtained from all participants prior to their enrollment in the study.

\section{Sample collection}

The sampling was conducted at the end of the work shift after 3-4 consecutive days of exposure. Personal monitors were used to assess airborne BTX concentration during the daily work shift, for approximately $8 \mathrm{~h}$. After air sampling, the samplers were stored at $-20^{\circ} \mathrm{C}$ until analysis. Urine samples were collected for benzene, toluene, and xylene metabolites and creatinine determination. The samples were stored in polyethylene bottles at $-80^{\circ} \mathrm{C}$ until further analysis. Venous blood samples were collected by venipuncture using vacuum tubes. EDTA-blood tubes were collected and centrifuged at $1500 \mathrm{~g}$ for $10 \mathrm{~min}$ at $4{ }^{\circ} \mathrm{C}$. Aliquots of EDTA-plasma were stored at $-80^{\circ} \mathrm{C}$ until analysis of the protein carbonyl content. A blood heparin tube was collected for glutathione S-transferase enzymatic activity determination and co-stimulatory molecules of CD80 e and CD86 assay analysis. A vacuum blood tube without anticoagulant was centrifuged at $1500 \mathrm{~g}$ for $10 \mathrm{~min}$ at room temperature. The serum obtained was aliquoted and stored at $-80{ }^{\circ} \mathrm{C}$ until inflammatory cytokine analysis. 


\section{Exposure assessment}

Personal breathing-zone air samples were collected using passive samplers (SKC 575-002 ${ }^{\circ}$ ). BTX (benzene, toluene, $o-, m-, p$-xylene) were desorbed with dichloromethane and analyzed by gas chromatography and flame ionization detection (GC-FID; PerkinElmer, USA). GC column Innowax $(25 \mathrm{~m}, 0.2 \mathrm{~mm}, 0.4 \mu \mathrm{m})$ was used. The initial oven temperature was $40{ }^{\circ} \mathrm{C}$, and the temperature was increased by $4^{\circ} \mathrm{C} \mathrm{min}{ }^{-1}$ until it reached $53^{\circ} \mathrm{C}$, followed by an oven ramp rate of $40^{\circ} \mathrm{C} \mathrm{min}^{-1}$ up to $200^{\circ} \mathrm{C}$. The FID detector temperature was kept at $250{ }^{\circ} \mathrm{C}$.

Quantification of urinary benzene metabolite (trans, trans-muconic acid - $t, t$-MA) was carried out by highperformance liquid chromatography with UV detection (HPLC-UV; Shimadzu, USA) after solid phase extraction (SPE) according to a previously described analytical method [18], with modifications as previously described [4]. Quantification of urinary metabolites of toluene (hippuric acid - HA) and xylene (methylhippuric acid mHA) were simultaneously performed by HPLC-UV [19]. The creatinine concentration was measured by spectrophotometry as previously described [20] using commercial kits (Doles reagents, Brazil).

\section{Immunological biomarkers}

CD80 and CD86 expression by monocytes was analyzed by flow cytometry. The samples were processed within $24 \mathrm{~h}$. Erythrocytes lysis was performed using an ammonium chloride solution $(0.13 \mathrm{M})$ and the leukocytes were resuspended with PBS buffer. $10^{6}$ leukocytes were incubated with PE-conjugated anti-CD80 and FITCconjugated anti-CD86. The antibodies were diluted 1: 100 with PBS and incubated in the dark at $4{ }^{\circ} \mathrm{C}$ for 20 min. Cells were analyzed by FACSC Canto II Flow Cytometer (Becton Dickinson, San Jose, CA) with Flow Jo Software (TreeStar). Monocyte cells were identified by manual gating according to side scatter and size.

\section{Inflammatory biomarkers}

Interleukin-1 $\beta$ (IL-1 $\beta$ ), interleukin-6 (IL-6), interleukin-10 (IL-10), tumor necrosis factor- $\alpha$ (TNF- $\alpha$ ), and interferon$\gamma($ IFN- $\gamma$ ) were analyzed using ELISA methods according to the manufacturer's instructions (Quantikine human immunoassays, R\&D Systems).

\section{Oxidative stress biomarkers}

Protein carbonyl (PCO) levels were determined using a noncompetitive ELISA method in accordance with Buss et al. [21] with some modifications. Total protein concentration in plasma was measured by the Bradford method using bovine serum albumin as standard. PCO levels were determined as follows: plasma samples were diluted with PBS buffer to a normalized concentration of $4 \mathrm{mg}$ protein $\mathrm{mL}^{-1}$ and then samples were derivatized with 2,4-dinitro- phenylhydrazine (DNPH) and incubated in Maxisorb multiwallplates (Nunc Immuno 96 MicrowellTM Maxisorp) overnight at $4{ }^{\circ} \mathrm{C}$ in the dark. Protein carbonyls were detected using a dinitrophenyl rabbit IgG-antiserum (Sigma) as the primary antibody and a monoclonal anti-rabbit immunoglobulin G peroxidase conjugate (Sigma) as the secondary antibody. Color development was performed with o-phenylenediamine and $\mathrm{H}_{2} \mathrm{O}_{2}$ and the reaction was stopped with $\mathrm{H}_{2} \mathrm{SO}_{4}$ after $15 \mathrm{~min}$ incubation at $37^{\circ} \mathrm{C}$. The absorbance was measured using a microplate reader with a detection wavelength of $492 \mathrm{~nm}$.

Glutathione S-transferase (GST) activity was performed in 96-well microplates and was read in a microplate reader (SpectraMax M2e, Molecular Devices), in accordance with Habig et al. [22]. GST was determined using CDNB (1chloro-2,4-dinitrobenzene) as substrate and 0.15 M GSH.

\section{Statistical analysis}

The data analysis was performed using the IBM SPSS Statistics software (version 19). All study variables were tested for normality using the Shapiro-Wilk test. Comparisons between groups were obtained using Student's t-test and the Mann-Whitney U-test. The results were expressed as mean \pm SEM or median (interquartile range), according to variable distribution. Correlation tests were performed using Pearson's correlation coefficient and Spearman's rank according to each variable. Multiple linear regression models were applied to verify the relation between BTX exposure, immunological biomarkers, inflammatory biomarkers, and oxidative stress biomarkers. The significance level for all tests was $p<0.05$.

\section{Results}

The data on environmental BTX exposure levels are reported in Table 1. The GSA group was exposed to significantly higher BTX concentrations than the non-exposed group $(p<0.001)$. Additionally, the data showed that the GSA group was exposed to very low levels of BTX, with all values found to be below the ACGIH (American Conference of Governmental Industrial Hygienists) limits.

Higher $t$, $t$-MA levels were found for the GSA group when compared to the non-exposed group $(p<0.001$; Table 1). Although the $t, t$-MA levels were higher in the GSA group compared to the non-exposed group, the median values were below the biological exposure index (BEI: $500 \mu \mathrm{g} \mathrm{g}^{-1}$ creatinine) established by the ACGIH.

The urinary biomarker of exposure to toluene was not significantly changed between the groups $(p>0.05$; Table 1). HA median values were below the biological limit value for occupationally exposed people (BEI: $1.6 \mathrm{~g}$ $\mathrm{g}^{-1}$ creatinine; ACGIH). Furthermore, the urinary biomarker of exposure to xylene could not be detected in any members of the study population (Table 1 ). 
Table 1 Environmental and biological monitoring

\begin{tabular}{|c|c|c|c|}
\hline & Non-exposed group $(n=28)$ & GSA group $(n=38)$ & ACGIH limits \\
\hline$\overline{\text { Benzene }\left(\mu \mathrm{g} \mathrm{m}^{-3}\right)}$ & $43.3(35.3-63.3)$ & $105.9(63.3-216.8)^{a}$ & 1600.0 \\
\hline 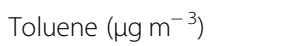 & $107.4(85.9-201.3)$ & $311.5(207.7-578.2)^{a}$ & $75,260.0$ \\
\hline o-Xylene $\left(\mu \mathrm{g} \mathrm{m}^{-3}\right)$ & $37.5(23.0-224.4)$ & $59.4(29.5-433.2)^{\mathrm{a}}$ & \\
\hline$m$-Xylene $\left(\mu \mathrm{g} \mathrm{m}^{-3}\right)$ & $20.1(17.4-25.6)$ & $32.5(27.8-37.4)^{\mathrm{a}}$ & $433,540.0^{*}$ \\
\hline p-Xylene $\left(\mu \mathrm{g} \mathrm{m}^{-3}\right)$ & $21.2(18.4-27.0)$ & $31.0(22.2-34.6)^{\mathrm{a}}$ & \\
\hline$t, t-M A\left(\mu g^{-1}\right.$ creatinine) & $74.8(47.6-121.5)$ & $421.9(292.2-694.6)^{\mathrm{a}}$ & 500.0 \\
\hline $\mathrm{HA}$ ( $\mathrm{g} \mathrm{g}^{-1}$ creatinine) & $0.3(0.2-0.4)$ & $0.3(0.2-0.6)$ & 1.6 \\
\hline m-HA ( $\mathrm{g} \mathrm{g}^{-1}$ creatinine) & n.d. & n.d. & 1.5 \\
\hline
\end{tabular}

The values are expressed as median (interquartile range)

t, $t$-MA trans,trans-muconic acid, HA hippuric acid, $m H A$ methylhippuric acid, n.d. not detectable

*total value to the sum of xylene isomers

${ }^{\mathrm{a}} p<0.001$

Figure 1 shows the immunological biomarker results. Decreased expression of CD80 (Fig. 1a) and CD86 (Fig. 1b) was observed in the membrane of monocytes of the GSA group compared to the non-exposed group $(p<0.001)$.

The cytokines levels are shown in Fig. 2. The GSA group showed increased levels of pro-inflammatory IL$1 \beta$, IL- 6 , TNF- $\alpha$, and IFN- $\gamma$ in relation to the nonexposed group $(p<0.001)$. In addition, reduced levels of anti-inflammatory IL-10 was observed in the GSA group compared to the non-exposed group $(p<0.001)$.

In relation to oxidative stress biomarkers, the protein damage was assessed through PCO levels (Fig. 3a). The GSA group showed an elevated PCO concentration compared to the non-exposed group $(p<0.001)$. The antioxidant status was evaluated through GST enzymatic activity (Fig. 3b). Decreased GST activity was observed in the GSA group compared to the non-exposed group $(p<0.05)$.

Univariate correlations were performed in all subjects, as a single sample. Strong correlations were found among the BTX organic solvents present in the gas station environment. Personal benzene exposure was positively correlated with airborne toluene concentration $(r=0.70 ; p<$ $0.001)$, $o$-xylene $(r=0.40 ; p<0.05), m$-xylene $(r=0.80$; $p<0.001)$, and $p$-xylene $(r=0.73 ; p<0.001)$ levels. Additionally, personal toluene exposure was also correlated with $o$-xylene $(r=0.40 ; p<0.05), m$-xylene $(r=0.75 ; p<$ $0.001)$, and $p$-xylene $(r=0.64 ; p<0.001)$ concentrations.

Also, the increased levels of personal benzene exposure was accompanied by urinary $t, t$-MA excretion $(r=$ $0.35 ; p<0.01)$. Environmental toluene and xylene levels were not significantly correlated with their urinary biomarkers $(p>0.05)$.

Environmental BTX levels and $t, t$-MA concentrations were significantly correlated with immunological, inflammatory, and oxidative stress biomarkers (Table 2).

Table 3 summarizes the correlations found among the evaluated biomarkers of effect. It was possible to observe significant correlations between immunological biomarkers and inflammatory biomarkers, immunological biomarkers and oxidative stress biomarkers, and oxidative stress biomarkers and inflammatory biomarkers. Furthermore, a negative correlation was observed between the oxidative stress biomarkers PCO levels and GST activity $(r=-0.31 ; p<0.05)$.

Exposure time was positively correlated with urinary $t, t$ MA levels $(r=0.67 ; p<0.001)$. Additional correlations between exposure time and immunological, inflammatory, and oxidative stress biomarkers are shown in Table 4.

Based on the correlations shown above, variables were selected to verify their influence on the increased pro-
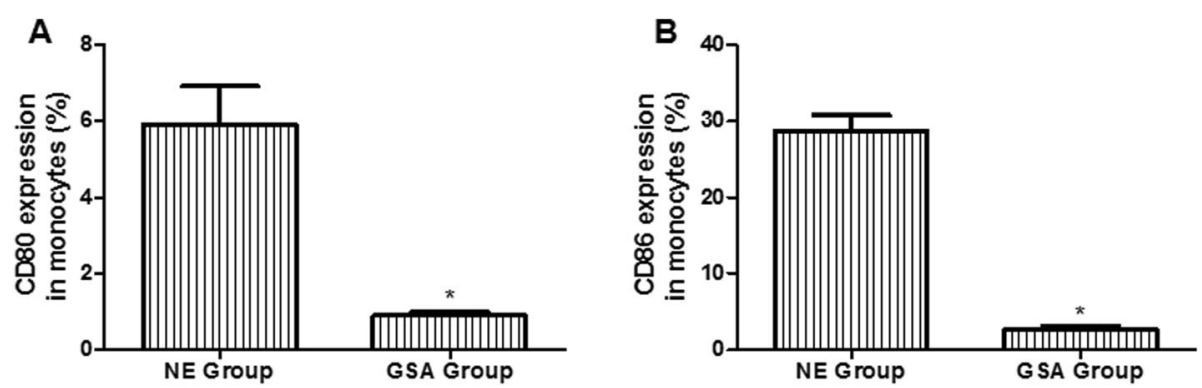

Fig. $1 \mathrm{Immunological}$ biomarkers in GSA group $(n=38)$ and non-exposed group $(n=28)$. a CD80 expression in monocytes. b CD86 expression in monocytes. Data are expressed as mean \pm SEM. ${ }^{*} p<0.001$ 


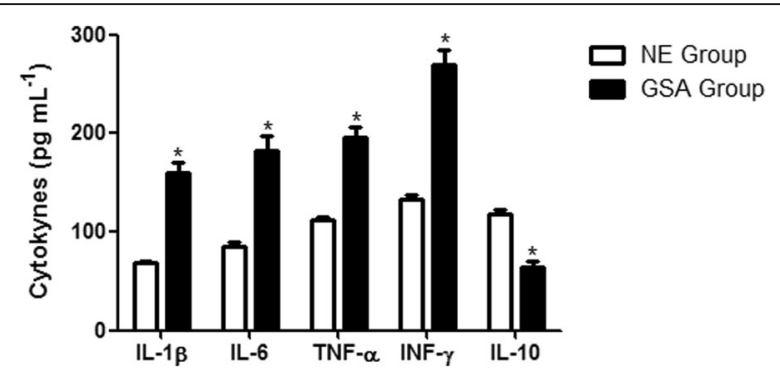

Fig. 2 Inflammatory biomarkers in GSA group $(n=38)$ and nonexposed group $(n=28)$. Data are expressed as mean \pm SEM. ${ }^{*} p<0.001$

inflammatory biomarkers (IL-1 $\beta$, IL- 6 , TNF- $\alpha$, and IFN$\gamma)$. The multiple linear regression model, displayed in Table 5, accounted for approximately $58,55,58$, and $63 \%$ of the increased pro-inflammatory cytokines IL-1 $\beta$, IL-6, TNF- $\alpha$, and IFN- $\gamma$, respectively. For all the inflammatory biomarkers, benzene exposure was the only factor that significantly contributed to the increased levels of the markers: IL-1 $\beta$ ( $\beta$ estimate $=0.437 ; p=0.018)$; IL-6 ( $\beta$ estimate $=0.519 ; p=0.007)$; TNF- $\alpha(\beta$ estimate $=0.496$; $p=0.008)$; and IFN $-\gamma(\beta$ estimate $=0.388 ; p=0.031)$.

\section{Discussion}

In this study, we observed the influence of BTX compound exposure on the immunological, inflammatory, and oxidative stress biomarkers evaluated. Furthermore, the data suggest that the immunological and inflammatory alterations observed in this study are interrelated, and connected to the imbalance of the oxidative status.

Personal occupational exposure to BTX, shown in our study, characterizes low-level exposure to these aromatic hydrocarbons, since all the found values were below the Threshold Limit Value-Time Weighted Average (TLVTWA) proposed by ACGIH for working environments. However, even so, it was possible to observe significantly higher levels of benzene, toluene, and xylene exposure in the GSA group compared to the non-exposed group. These findings are in accordance with previous studies that have also found airborne BTX concentrations lower than the ACGIH limits [2-4, 11, 17]. Additionally, the strong correlations shown between airborne BTX concentrations evidenced that the GSA group was exposed to a mixture of multiple organic solvents.

According to Carrieri et al. [3], urinary t,t-MA is a widely used biomarker in routine practice for the biological monitoring of benzene exposure, mainly because of the simple analytical method used for its determination, easily available in most industrial and environmental toxicology laboratories. However, diet and smoking interference in this biomarker of exposure may compromise its specificity. Despite that, in our study, $t, t$-MA was confirmed as a good indicator of exposure to low levels of benzene exposure, since there were significantly elevated levels in the GSA group in relation to the non-exposed group. In addition, $t, t$-MA excretion correlated with personal benzene exposure, which points to the relevance of this biomarker of exposure, even at reduced levels. The same cannot be visualized for the urinary biomarker of exposure to toluene, since HA did not show any significant difference between the groups, nor was it correlated with personal toluene exposure, as previously shown in studies by our group $[4,17]$. Also, m-HA, urinary biomarker of xylene exposure, did not prove to be a good marker.

The alterations observed in the immunological biomarkers evaluated in our study (CD80 and CD86 expression in monocytes) are in accordance with previously described data $[2,4,17]$. Furthermore, the univariate correlations showed that the reduced expressions of CD80 and CD86 were related to BTX exposure, proving the interference of these chemical compounds in the immune system of occupationally exposed individuals.

The co-stimulatory molecules CD80 and CD86 are recognized as the main co-stimulatory molecules of the immune system [17], and are considered one of the most important signaling mechanisms and regulators of adaptive cellular immunity $[23,24]$. The absence or depletion of these co-stimulatory molecules results in hyporresponsiveness, development of anergic $\mathrm{T}$ cells, or inefficient immune surveillance [17, 25, 26]. According to Sauer et al. [17], immunological alterations, as observed in our study, could
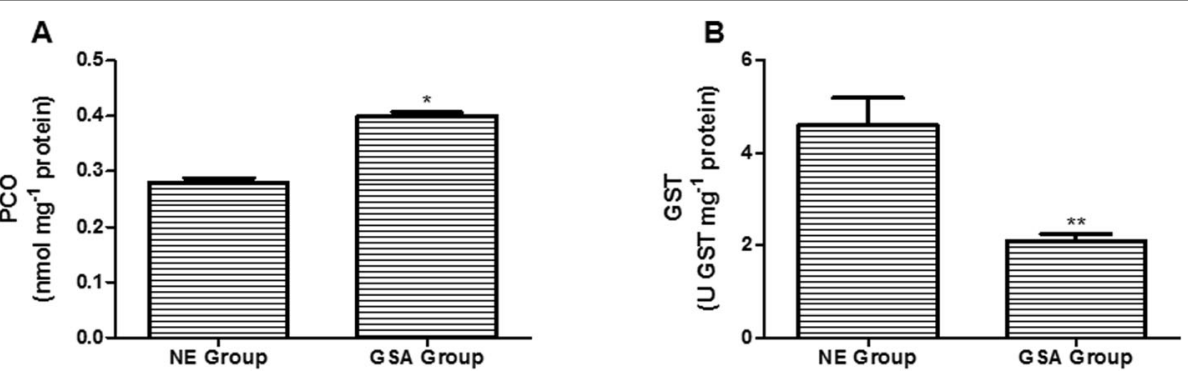

Fig. 3 Oxidative stress biomarkers in GSA group $(n=38)$ and non-exposed group $(n=28)$. a Protein carbonyl (PCO) levels. b Glutathione S-transferase (GST) activity. Data are expressed as mean \pm SEM. ${ }^{*} p<0.001 .{ }^{* *} p<0.05$ 
Table 2 Spearman's correlations among personal BTX exposure, trans,trans-muconic acid, immunological, inflammatory, and oxidative stress biomarkers $(n=66)$

\begin{tabular}{|c|c|c|c|c|c|c|}
\hline & $\begin{array}{l}\text { Benzene } \\
\left(\mu \mathrm{g} \mathrm{m}^{-3}\right)\end{array}$ & $\begin{array}{l}\text { Toluene } \\
\left(\mu \mathrm{g} \mathrm{m}^{-3}\right)\end{array}$ & $\begin{array}{l}\text { o-Xylene } \\
\left(\mu \mathrm{g} \mathrm{m}^{-3}\right)\end{array}$ & $\begin{array}{l}\text { m-Xylene } \\
\left(\mu \mathrm{g} \mathrm{m}^{-3}\right)\end{array}$ & $\begin{array}{l}\text { p-Xylene } \\
\left(\mu \mathrm{g} \mathrm{m}^{-3}\right)\end{array}$ & $\begin{array}{l}t, t-M A\left(\mu g g^{-1}\right. \\
\text { creatinine) }\end{array}$ \\
\hline $\begin{array}{l}\text { CD80 monocyte } \\
\text { expression (\%) }\end{array}$ & $r=-0.26(p<0.05)$ & $r=-0.32(p<0.05)$ & $p>0.05$ & $p>0.05$ & $p>0.05$ & $r=-0.43(p<0.001)$ \\
\hline $\begin{array}{l}\text { CD86 monocyte } \\
\text { expression (\%) }\end{array}$ & $r=-0.46(p<0.001)$ & $r=-0.58(p<0.001)$ & $r=-0.43(p<0.05)$ & $r=-0.41(p<0.05)$ & $r=-0.43(p<0.05)$ & $r=-0.47(p<0.001)$ \\
\hline$\| \mathrm{L}-1 \beta\left(p g \mathrm{~mL}^{-1}\right)$ & $r=0.43(p<0.001)$ & $r=0.37(p<0.05)$ & $p>0.05$ & $r=0.46(p<0.05)$ & $r=0.39(p<0.05)$ & $r=0.54(p<0.001)$ \\
\hline IL-6 $\left(p g \mathrm{~mL}^{-1}\right)$ & $r=0.38(p<0.05)$ & $r=0.37(p<0.05)$ & $p>0.05$ & $r=0.40(p<0.05)$ & $r=0.36(p<0.05)$ & $r=0.50(p<0.001)$ \\
\hline $\mathrm{IL}-10\left(\mathrm{pg} \mathrm{mL} \mathrm{L}^{-1}\right)$ & $r=-0.36(p<0.001)$ & $r=-0.38(p<0.05)$ & $p>0.05$ & $r=-0.44(p<0.05)$ & $r=-0.34(p<0.05)$ & $r=-0.54(p<0.001)$ \\
\hline TNF-a $\left(\mathrm{pg} \mathrm{mL}^{-1}\right)$ & $r=0.43(p<0.001)$ & $r=0.41(p<0.05)$ & $p>0.05$ & $r=0.37(p<0.05)$ & $r=0.35(p<0.05)$ & $r=0.48(p<0.001)$ \\
\hline INF- $\gamma\left(\mathrm{pg} \mathrm{mL}^{-1}\right)$ & $r=0.47(p<0.001)$ & $r=0.44(p<0.001)$ & $p>0.05$ & $r=0.41(p<0.05)$ & $r=0.40(p<0.05)$ & $r=0.59(p<0.001)$ \\
\hline $\begin{array}{l}\text { PCO }\left(\mathrm{nmol} \mathrm{mg}^{-1}\right. \\
\text { protein) }\end{array}$ & $r=0.46(p<0.001)$ & $r=0.45(p<0.001)$ & $p>0.05$ & $r=0.49(p<0.001)$ & $r=0.45(p<0.05)$ & $r=0.64(p<0.001)$ \\
\hline $\begin{array}{l}\text { GST (U GST mg }{ }^{-1} \\
\text { protein) }\end{array}$ & $p>0.05$ & $p>0.05$ & $p>0.05$ & $r=-0.34(p<0.05)$ & $r=-0.34(p<0.05)$ & $r=-0.26(p<0.05)$ \\
\hline
\end{tabular}

$t, t-M A$ trans,trans-muconic acid, IL-1 $\beta$ interleukin-1 $\beta, I L-6$ interleukin- $6, I L-10$ interleukin-10, TNF- $a$ tumor necrosis factor- $\alpha$, IFN- $\gamma$ interferon- $\gamma, P C O$ protein carbonyl, GST glutathione S-transferase

contribute to the development of benzene immunocarcinogenic effects, since it is known that the immune system is highly involved in carcinogenesis.

The GSA group evaluated in our study presented increased pro-inflammatory cytokines (IL-1 $\beta$, IL-6, TNF- $\alpha$, and IFN- $\gamma$ ), accompanied by decreased levels of the antiinflammatory IL-10 cytokine, which is in accordance with previous literature [27]. Although the lower expression of the CD80 and CD86 adhesion molecules are linked to an ineffective immune response, and consequently, to a compromised inflammatory response, studies have shown that chronic exposure to toxic agents, such as BTX compounds, could contribute to the development of an inflammatory process, which is involved in the development of different types of cancer and tumor progress $[28,29]$. In addition, during the hepatic biotransformation of BTX compounds, many oxidative and reactive species are produced, which could contribute to the increased of pro-inflammatory cytokines, as evidenced in our results through of moderate correlations among immunological and inflammation biomarkers. CD86 expression in monocytes was positively correlated with IL-10 levels and negatively associated with proinflammatory biomarkers. These data suggest an immunological impairment scenario, accompanied by an inflammatory process, which could contribute to carcinogenesis, as described above.

According Spatari et al. [30], aromatic hydrocarbons found in fuel are active agents responsible for suppressing immune response. In our study, according to the multiple linear regression model, personal benzene exposure was the only variable that significantly contributed to the increased levels of the pro-inflammatory biomarkers (IL-1 $\beta$, IL-6, TNF- $\alpha$, and IFN- $\gamma$ ), These

Table 3 Correlations among biomarkers of effect $(n=66)$

Immunological biomarkers vs. Inflammatory biomarkers

\begin{tabular}{|c|c|c|c|c|c|}
\hline & $\mathrm{IL}-1 \beta\left(\mathrm{pg} \mathrm{mL} \mathrm{L}^{-1}\right)$ & $\mathrm{IL}-6\left(\mathrm{pg} \mathrm{mL}{ }^{-1}\right)$ & $\mathrm{IL}-10\left(\mathrm{pg} \mathrm{mL} \mathrm{L}^{-1}\right)$ & TNF-a $\left(\mathrm{pg} \mathrm{mL}^{-1}\right)$ & INF- $Y\left(\mu g \mathrm{~mL}^{-1}\right)$ \\
\hline CD80 monocyte expression (\%) & $p>0.05$ & $p>0.05$ & $r=0.28(p<0.05)$ & $p>0.05$ & $r=-0.31(p<0.05)$ \\
\hline CD86 monocyte expression (\%) & $r=-0.27(p<0.05)$ & $r=-0.29(p<0.05)$ & $r=0.28(p<0.05)$ & $r=-0.35(p<0.05)$ & $r=-0.42(p<0.001)$ \\
\hline
\end{tabular}

Immunological biomarkers vs. Oxidative Stress biomarkers

$\begin{array}{ll} & \text { PCO (nmol } \mathrm{mg}^{-1} \text { protein) } \\ \text { CD80 monocyte expression (\%) } & r=-0.41(p<0.001) \\ \text { CD86 monocyte expression (\%) } & r=-0.43(p<0.001)\end{array}$

GST (U GST $\mathrm{mg}^{-1}$ protein)

$p>0.05$

$p>0.05$

Oxidative Stress biomarkers vs. Inflammatory biomarkers

\begin{tabular}{|c|c|c|c|c|c|}
\hline & $\mathrm{IL}-1 \beta\left(p g \mathrm{~mL}^{-1}\right)$ & IL-6 (pg mL $\left.{ }^{-1}\right)$ & $\mathrm{IL}-10(\mathrm{pg} \mathrm{mL}-1)$ & TNF-a $\left(p g \mathrm{~mL}^{-1}\right)$ & INF-Y $\left(p g \mathrm{~mL}^{-1}\right)$ \\
\hline PCO (nmol mg ${ }^{-1}$ protein) & $r=0.51(p<0.001)$ & $r=0.49(p<0.001)$ & $r=-0.42(p<0.001)$ & $r=0.46(p<0.001)$ & $r=0.54(p<0.001)$ \\
\hline GST (U GST mg ${ }^{-1}$ protein) & $r=-0.29(p<0.05)$ & $r=-0.28(p<0.05)$ & $p>0.05$ & $r=-0.35(p<0.05)$ & $r=-0.39(p<0.001)$ \\
\hline
\end{tabular}


Table 4 Correlations among exposure time and immunological, inflammatory, and oxidative stress biomarkers $(n=66)$

\begin{tabular}{|c|c|}
\hline & Exposure time (years) \\
\hline CD80 monocyte expression (\%) & $r=-0.34(p<0.05)$ \\
\hline CD86 monocyte expression (\%) & $r=-0.50(p<0.001)$ \\
\hline $\mathbb{L}-1 \beta\left(p g \mathrm{~mL}^{-1}\right)$ & $r=0.57(p<0.001)$ \\
\hline IL-6 $\left(p g ~ m L^{-1}\right)$ & $r=0.54(p<0.001)$ \\
\hline $\mathrm{IL}-10\left(\mathrm{pg} \mathrm{mL}^{-1}\right)$ & $r=-0.56(p<0.001)$ \\
\hline TNF-a $\left(p g \mathrm{~mL}^{-1}\right)$ & $r=0.53(p<0.001)$ \\
\hline INF- $\gamma\left(p g \mathrm{~mL}^{-1}\right)$ & $r=0.59(p<0.001)$ \\
\hline PCO (nmol mg ${ }^{-1}$ protein) & $r=0.58(p<0.001)$ \\
\hline GST (U GST mg ${ }^{-1}$ protein) & $r=-0.27(p<0.05)$ \\
\hline
\end{tabular}

IL-1 $\beta$ interleukin-1 $\beta$, IL-6 interleukin-6, IL-10 interleukin-10, TNF- $\alpha$ tumor necrosis factor- $\alpha$, IFN- $\gamma$ interferon- $\gamma, P C O$ protein carbonyl, GST glutathione S-transferase

findings suggested that the immunological and inflammatory alterations observed in our study could be related to carcinogenic process development due to benzene exposure. However, additional and further studies are needed to confirm this hypothesis.

The immunological and inflammatory alterations observed in our study are connected to the oxidative stress biomarkers, which could be shown by the univariate correlations. Additionally, the GSA group showed increased levels of PCO accompanied by decreased GST activity when compared to the non-exposed group. Furthermore, these alterations were linked to BTX exposure, confirming the involvement of these xenobiotics in the imbalance of the oxidative status observed.

According to Barreto et al. [31], during the biotransformation of benzene, multiple forms of reactive species are produced, which could contribute to the development of oxidative damage, and could be the cause of increased levels of the biomarkers of protein damage observed in our study. Besides oxidative damage to protein, the continuous production of reactive species during benzene metabolism could induce toxicity in key cellular components, such as DNA [32]. Indeed, the activation of benzene and its metabolites culminates in damage to lipids, proteins, and DNA carbohydrates through various chemical reactions, leading to functional alterations in different tissues [33]. Furthermore, chronic benzene exposure compromises antioxidant capacity, which also contributes to the development of oxidative damage in exposed individuals [10,34].

All the immunological, inflammatory, and oxidative stress biomarkers evaluated were correlated with exposure time. These findings indicate the possibility of using these biomarkers in the continuous monitoring of occupational hazards.

\section{Conclusions}

The main findings of this study are related to the fact that all the alterations evidenced could be involved in the damage caused by occupational benzene exposure, especially the inflammatory process, which had not yet been detected in previous studies of our group, involving individuals occupationally exposed to benzene. Additional studies should be performed to elucidate the potential involvement of each biomarker. However, the continuous monitoring of these biomarkers could contribute to the early detection of the damages caused by benzene.

Table 5 Multiple linear regression models

\begin{tabular}{|c|c|c|c|c|c|c|c|c|}
\hline & \multicolumn{2}{|c|}{$\| \mathrm{L}-1 \beta\left(\mathrm{pg} \mathrm{mL} \mathrm{L}^{-1}\right)$} & \multicolumn{2}{|c|}{ IL-6 (pg mL $\left.\mathrm{m}^{-1}\right)$} & \multicolumn{2}{|c|}{ TNF-a $\left(p g \mathrm{~mL}^{-1}\right)$} & \multicolumn{2}{|c|}{ INF- $\gamma\left(\mathrm{pg} \mathrm{mL}^{-1}\right)$} \\
\hline & \multicolumn{2}{|c|}{$R$ square $=0.579$} & \multicolumn{2}{|c|}{$R$ square $=0.555$} & \multicolumn{2}{|c|}{$R$ square $=0.584$} & \multicolumn{2}{|c|}{$R$ square $=0.627$} \\
\hline & $B$ & $p$-values & $\beta$ & $p$-values & $\beta$ & $p$-values & $\beta$ & $p$-values \\
\hline Benzene $\left(\mu \mathrm{g} \mathrm{m}^{-3}\right)^{a}$ & 0.437 & $p<0.05$ & 0.519 & $p<0.05$ & 0.496 & $p<0.05$ & 0.388 & $p<0.05$ \\
\hline Toluene $\left(\mu \mathrm{g} \mathrm{m}^{-3}\right)^{\mathrm{a}}$ & 0.213 & $p>0.05$ & 0.270 & $p>0.05$ & 0.221 & $p>0.05$ & 0.268 & $p>0.05$ \\
\hline$m$-Xylene $\left(\mu \mathrm{g} \mathrm{m}^{-3}\right)^{\mathrm{a}}$ & -0.250 & $p>0.05$ & -0.182 & $p>0.05$ & -0.333 & $p>0.05$ & -0.080 & $p>0.05$ \\
\hline p-Xylene $\left(\mu \mathrm{g} \mathrm{m}^{-3}\right)^{a}$ & -0.259 & $p>0.05$ & -0.285 & $p>0.05$ & -0.349 & $p>0.05$ & -0.177 & $p>0.05$ \\
\hline t,t-MA ( $\mu \mathrm{g} \mathrm{g}^{-1}$ creatinine) $^{\mathrm{a}}$ & -0.319 & $p>0.05$ & -0.212 & $p>0.05$ & -0.300 & $p>0.05$ & -0.058 & $p>0.05$ \\
\hline CD86 monocyte expression (\%) & -0.404 & $p>0.05$ & -0.381 & $p>0.05$ & -0.428 & $p>0.05$ & -0.374 & $p>0.05$ \\
\hline PCO (nmol mg ${ }^{-1}$ protein) ${ }^{a}$ & 0.140 & $p>0.05$ & 0.017 & $p>0.05$ & 0.051 & $p>0.05$ & 0.053 & $p>0.05$ \\
\hline GST (U GST mg ${ }^{-1}$ protein) ${ }^{a}$ & -0.165 & $p>0.05$ & -0.071 & $p>0.05$ & -0.196 & $p>0.05$ & -0.155 & $p>0.05$ \\
\hline Exposure time $(y e a r s)^{a}$ & -0.463 & $p>0.05$ & -0.481 & $p>0.05$ & -0.461 & $p>0.05$ & -0.387 & $p>0.05$ \\
\hline Age $(\text { years) })^{a}$ & 0.277 & $p>0.05$ & 0.229 & $p>0.05$ & 0.148 & $p>0.05$ & 0.161 & $p>0.05$ \\
\hline Smoking ${ }^{b}$ & -0.129 & $p>0.05$ & -0.087 & $p>0.05$ & -0.085 & $p>0.05$ & -0.123 & $p>0.05$ \\
\hline
\end{tabular}

$t, t-M A$ trans, trans-muconic acid, IL-1 $\beta$ interleukin- $1 \beta$, IL-6 interleukin-6, TNF- $\alpha$ tumor necrosis factor- $\alpha$, IFN- $\gamma$ interferon- $\gamma, P C O$ protein carbonyl, GST glutathione S-transferase

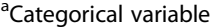

${ }^{\mathrm{b}}$ Continuous variable 
Taken together, these findings showed the influence of exposure to BTX compounds, especially benzene, on the immunological, inflammatory, and oxidative stress biomarkers evaluated. Furthermore, the data suggest a relationship among the evaluated biomarkers of effect, which, if continuously monitored, could contribute to providing early signs of damage to biomolecules in subjects that are occupationally exposed to BTX compounds. Additional measures, such as antioxidant intake, exposure elimination, also could contribute to the improvement of the life quality of occupational exposed subjects.

\begin{abstract}
Abbreviations
ACGIH: American Conference of Governmental Industrial Hygienists; BEI: Biological exposure index; BTX: Benzene, toluene, and xylene; EDTA: Ethylenediamine tetra-acetic acid; GC-FID: Gas chromatographic flame ionization detector; GSA: Gasoline station attendants; GST: Glutathione S-transferase; HA: Hippuric acid; HPLC-UV: High-performance liquid chromatography with UV detection; IFN- $\gamma$ : Interferon- $\gamma$; IL-10: Interleukin-10; IL-1ß: Interleukin-1 B; IL-6: Interleukin-6; mHA: Methylhippuric acid; NE: Nonexposed; PCO: Protein carbonyl; SEM: Standard error of the mean; SPE: Solid phase extraction; t, t-MA: trans, trans-muconic acid; TLV-TWA: Threshold Limit Value-Time Weighted Average; TNF-a: Tumor necrosis factor-a
\end{abstract}

\section{Acknowledgements}

The authors would like to thank all the subjects who volunteered to participate in this study.

\section{About this supplement}

This article has been published as part of BMC Pharmacology and Toxicology Volume 20 Supplement 1, 2019: Proceedings of Toxi-Latin 2018. The full contents of the supplement are available online at https:// bmcpharmacoltoxicol.biomedcentral.com/articles/supplements/volume-20supplement-1.

\section{Authors' contributions}

AMM designed the study and drafted the manuscript; ES performed the experimental analysis and contributed to the data collection; NB performed the experimental analysis and contributed to the data collection; MFC performed the experimental analysis and contributed to the data collection; BG performed the experimental analysis and contributed to the data collection; SNN performed the experimental analysis and contributed to the data collection; GG performed the experimental analysis and contributed to the data collection; MMMFD performed the experimental analysis; SCG contributed to the interpretation and reviewed the draft of the manuscript. All authors read and approved the final manuscript.

\section{Funding}

This study was supported by CNPq/Universal (grant to S.C. Garcia; case nos. 484096/2011-7 and 485342/2013-8) and FAPERGS (grant to S.C. Garcia; case no. 1017503 PqG 06/2010 and PPSUS case no. 1207-2551/13-9). Publication costs were funded by CNPq/Universal and FAPERGS.

\section{Availability of data and materials}

The datasets used and/or analyzed during this study are available from the corresponding author on reasonable request.

\section{Ethics approval and consent to participate}

This study was approved by the research ethics committee of the Federal University of Rio Grande do Sul/RS (No. 21728/11) and a written informed consent was obtained from all participants prior to their enrollment in the study.

\section{Consent for publication}

Not applicable.

\section{Competing interests}

The authors declare that they have no competing interests.

\section{Author details}

'Laboratory of Toxicology (LATOX), Department of Analysis, Pharmacy Faculty, Federal University of Rio Grande do Sul, Porto Alegre, RS, Brazil. ${ }^{2}$ Specialized Faculty in the Health Area of Rio Grande do Sul (FASURGS), Passo Fundo, RS, Brazil. ${ }^{3}$ Post-graduate Program in Pharmaceutical Sciences, Federal University of Rio Grande do Sul, Avenida Ipiranga 2752, Santa Cecília, Porto Alegre, RS CEP: 90610-000, Brazil. ${ }^{4}$ Department of Physiology and Pharmacology, Federal University of Santa Maria, Santa Maria, RS, Brazil. ${ }^{5}$ Health Sciences Institute, Feevale University, Novo Hamburgo, RS, Brazil. ${ }^{6}$ Department of Health Sciences, Lutheran University of Brazil, Santa Maria, RS, Brazil.

Published: 19 December 2019

\section{References}

1. Dougherty D, Garte S, Barchowsky A, Zmuda J, Taioli E. NQO1, MPO, CYP2E1, GSTT1 and GSTM1 polymorphisms and biological effects of benzene exposure--a literature review. Toxicol Lett. 2008:182(1-3):7-17.

2. Moro AM, Brucker N, Charao MF, Baierle M, Sauer E, Goethel G, et al. Biomonitoring of gasoline station attendants exposed to benzene: effect of gender. Mutat Res. 2017:813:1-9.

3. Carrieri M, Spatari G, Tranfo G, Sapienza D, Scapellato ML, Bartolucci GB, et al. Biological monitoring of low level exposure to benzene in an oil refinery: effect of modulating factors. Toxicol Lett. 2018:298:70-5.

4. Moro AM, Brucker N, Charao MF, Sauer E, Freitas F, Durgante J, et al. Early hematological and immunological alterations in gasoline station attendants exposed to benzene. Environ Res. 2015;137:349-56.

5. Salem E, El-Garawani I, Allam H, El-Aal BA, Hegazy M. Genotoxic effects of occupational exposure to benzene in gasoline station workers. Ind Health. 2018:56(2):132-40.

6. Warden H, Richardson H, Richardson L, Siemiatycki J, Ho V. Associations between occupational exposure to benzene, toluene and xylene and risk of lung cancer in Montreal. Occup Environ Med. 2018:75:696-702.

7. Keenan JJ, Gaffney SH, Galbraith DA, Beatty P, Paustenbach DJ. Gasoline: a complex chemical mixture, or a dangerous vehicle for benzene exposure? Chem Biol Interact. 2010;184(1-2):293-5.

8. Weisel CP. Benzene exposure: an overview of monitoring methods and their findings. Chem Biol Interact. 2010;184(1-2):58-66.

9. De Palma G, Poli D, Manini P, Andreoli R, Mozzoni P, Apostoli P, et al. Biomarkers of exposure to aromatic hydrocarbons and methyl tert-butyl ether in petrol station workers. Biomarkers. 2012:17(4):343-51.

10. Uzma N, Kumar BS, Hazari MA. Exposure to benzene induces oxidative stress, alters the immune response and expression of p53 in gasoline filling workers. Am J Ind Med. 2010:53(12):1264-70.

11. Moro AM, Charao MF, Brucker N, Durgante J, Baierle M, Bubols G, et al. Genotoxicity and oxidative stress in gasoline station attendants. Mutat Res. 2013;754(1-2):63-70.

12. Bahadar H, Mostafalou S, Abdollahi M. Current understandings and perspectives on non-cancer health effects of benzene: a global concern. Toxicol Appl Pharmacol. 2014;276(2):83-94.

13. Protano C, Andreoli R, Manini P, Vitali M. Urinary trans, trans-muconic acid and S-phenylmercapturic acid are indicative of exposure to urban benzene pollution during childhood. Sci Total Environ. 2012;435-436:115-23.

14. Tunsaringkarn T. Benzene-induced changes in hematological parameters and urinary trans, trans-muconic acid among gasoline station workers: authors' reply. Int J Occup Environ Med. 2013:4(2):110.

15. Hays SM, Pyatt DW, Kirman CR, Aylward LL. Biomonitoring equivalents for benzene. Regul Toxicol Pharmacol. 2012;62(1):62-73.

16. Tunsaringkarn T, Suwansaksri J, Soogarun S, Siriwong W, Rungsiyothin A, Zapuang K, et al. Genotoxic monitoring and benzene exposure assessment of gasoline station workers in metropolitan Bangkok: sister chromatid exchange (SCE) and urinary trans, trans-muconic acid (t,t-MA). Asian Pac J Cancer Prev. 2011;12(1):223-7.

17. Sauer E, Gauer B, Nascimento S, Nardi J, Goethel G, Costa B, et al. The role of B7 costimulation in benzene immunotoxicity and its potential association with cancer risk. Environ Res. 2018;166:91-9.

18. Ducos P, Gaudin R, Robert A, Francin JM, Maire C. Improvement in HPLC analysis of urinary trans,trans-muconic acid, a promising substitute for phenol in the assessment of benzene exposure. Int Arch Occup Environ Health. 1990;62(7):529-34. 
19. Bulcão R, Santa Maria L, Charão M, Moro A, Roehrs M, Garcia S. Quantificação simultânea de indicadores biológicos de exposição a solventes orgânicos por cromatografia líquida de alta eficiência. Quim Nova. 2008:31:1343-8.

20. Jaffe N, Keifer R 3rd, Robertson R, Cangir A, Wang A. Renal toxicity with cumulative doses of cis-diamminedichloroplatinum-II in pediatric patients with osteosarcoma. Effect on creatinine clearance and methotrexate excretion. Cancer. 1987;59(9):1577-81.

21. Buss H, Chan TP, Sluis KB, Domigan NM, Winterbourn CC. Protein carbonyl measurement by a sensitive ELISA method. Free Radic Biol Med. 1997;23(3):361-6.

22. Habig WH, Keen JH, Jakoby WB. Glutathione S-transferase in the formation of cyanide from organic thiocyantes and as an organic nitrate reductase. Biochem Biophys Res Commun. 1975;64(2):501-6.

23. Greaves $\mathrm{P}$, Gribben JG. The role of B7 family molecules in hematologic malignancy. Blood. 2013;121(5):734-44.

24. Baumeister SH, Freeman GJ, Dranoff G, Sharpe AH. Coinhibitory pathways in immunotherapy for Cancer. Annu Rev Immunol. 2016;34:539-73.

25. Dai ZS, Chen QF, Lu HZ, Xie Y. Defective expression and modulation of B72/CD86 on B cells in B cell chronic lymphocytic leukemia. Int J Hematol. 2009;89(5):656-63.

26. Dolen Y, Esendagli G. Myeloid leukemia cells with a B7-2(+) subpopulation provoke Th-cell responses and become immuno-suppressive through the modulation of B7 ligands. Eur J Immunol. 2013;43(3):747-57.

27. Mosser DM, Zhang X. Interleukin-10: new perspectives on an old cytokine. Immunol Rev. 2008;226:205-18.

28. Stokes MA, Guest GD, Mamadi P, Seta W, Yaubihi N, Karawiga G, et al. Measuring the burden of surgical disease averted by emergency and essential surgical care in a district hospital in Papua New Guinea. World J Surg. 2017;41(3):650-9.

29. Lin WW, Karin M. A cytokine-mediated link between innate immunity, inflammation, and cancer. J Clin Invest. 2007;117(5):1175-83.

30. Spatari G, Saitta S, Giorgianni C, Cristani MT, Quattrocchi P, Abbate A, et al. Interleukin-10 involvement in exposure to low dose of benzene. Toxicol Ind Health. 2015;31(4):351-4.

31. Barreto G, Madureira D, Capani F, Aon-Bertolino L, Saraceno E, AlvarezGiraldez LD. The role of catechols and free radicals in benzene toxicity: an oxidative DNA damage pathway. Environ Mol Mutagen. 2009:50(9):771-80.

32. Badham HJ, Renaud SJ, Wan J, Winn LM. Benzene-initiated oxidative stress: effects on embryonic signaling pathways. Chem Biol Interact. 2010;184(1-2):218-21.

33. Badham HJ, Winn LM. In utero exposure to benzene disrupts fetal hematopoietic progenitor cell growth via reactive oxygen species. Toxicol Sci. 2010;113(1):207-15.

34. Keretetse GS, Laubscher PJ, Du Plessis IL, Pretorius PJ, Van Der Westhuizen $\mathrm{FH}$, Van Deventer $\mathrm{E}$, et al. DNA damage and repair detected by the comet assay in lymphocytes of african petrol attendants: a pilot study. Ann Occup Hyg. 2008;52(7):653-62.

\section{Publisher's Note}

Springer Nature remains neutral with regard to jurisdictional claims in published maps and institutional affiliations.

Ready to submit your research? Choose BMC and benefit from:

- fast, convenient online submission

- thorough peer review by experienced researchers in your field

- rapid publication on acceptance

- support for research data, including large and complex data types

- gold Open Access which fosters wider collaboration and increased citations

- maximum visibility for your research: over $100 \mathrm{M}$ website views per year

At $\mathrm{BMC}$, research is always in progress.

Learn more biomedcentral.com/submissions 